\title{
LIST OF SPECIES OF BUTTERFLIES RECEIVED FROM FORT NIOBRARA, NEBRASKA.
}

BY W. L. CARPENTER.

Pieris protodice, Bois. Colias eurytheme, Bois. Nathalis jole, Bois.

Argynnis cybele, Fabr. " aphrodite, Fabr.

Euptoieta claudia, Cramer.

Phyciodes nycteis, Doubl.

" tharos, Irury.

Grapta interrogationis, Fab.

" comma, dryas, Edw.

" progne, Cramer.

Limenitis Weidemeyerii, Edw,

Apatura celtis, Bois.
Debis portlandia, Fab.

Satyrus nephele, olympus, Edw.

Neonympha eurytris, Fabr.

Thecla strigosa, Harr.

" calanus, Hubn.

Lycaena comyntas, Godt.

" neglecta, Edw.

Pamphila zabulon, Bois.

" manataaqua, Scud.

" huron, Edw.

Pyrgus tessellata, Scud.

Eudamus bathyllus, Sm.-Abbot.

" tityrus, Fabr.

ON "THE WHITE SCALE OF THE ORANGE."

(Ceropiastes rusci Linn.)

BY WMI, H. ASHAEAD, JACKSONVILLF, FLORIDA.

DIBLIOGRAPHICAL.

Coccus rusci Linn., Sys. Nat.; Fab., Syst. Ent. (1775); Id., Spec. Ins. (I78I); Id., Sys. Ryng. (I 803 ); Id., iviantis. Ins. (I 787 ); Id., Ent. Sys. (I 794); Modeer., Act. Goth. (I778); Gmelin., Syst. Nat. (I79I); Oliv., Encyc. Meth. ( 79 r.) C. caricae Fab., Ent. Syst. (. 794); Id., Syst. Ryng. (1804); Bernard Mem. Hist. Nat. et. Mem. Acad. (1775); Fronscol Ann. Soc. Ent. Fr. (1 834); Boisduval Ent. Hort. (1868). Lopus tesselata Klein. (I 734). Calypticus testudineus Costa (1837); Faun., Regn. Nap. Gallins. Columnea testudinata Targioni (I866); Atti dei Georgof; Id., Studi Sulle Coccinig ext Soc. Ital. Scien. Milan et Catal (1868). Signoret.

This is another scale found by me infesting the orange trees in Florida. It has a wide distribution, being found in Europe, Australia and the southern parts of America. 
Like the Long Scale (Aspidiotus Gloverii), it has probably been imported into this country, and but recently, as I can find no record of its having been found in Florida several years back. It is now just beginning to become common.

\section{ITS FOOD PLANT.}

M. Signoret, "Essai sur le Cochinelles," gives its food plants in Europe as the myrtle, common holly and wormwood. In Florida I have found it on the myrtle, orange, fig and oleander. Prof. J. H. Comstock, on his recent tour to Florida, told me he had found it also on the gallberry (Ilex glaber.)

The Scale, fig. 25: when fully matured, averages from . 10 to .I4 of an inch in length, by from .06 to .08 in width, and is highly arched. On the top it is tesselated with seven well-defined, oval, elevated checkers, three on each side, nearly round, the seventh, at posterior end, being more or less triangular. At.first, the color is whitish, resembling wax, with which it is similar in consistency, being, soft and pliable. As it reaches maturity it becomes pinkish with a slight yellowish tint in depressions; just before the young hatch, it becomes of a globular form, and the top changes to a dark brown.

The summer-brood of young hatch in from ten to twenty days after the eggs have been laid. The female is flattened, oval, resembling in shape the wood-louse, only not so convex. It is pale yellowish, with a brownish tint on back; antennæ six-jointed; in the posterior end is a deep triangular-shaped indentation, from the centre of which protrudes a fleshy tubercle, reaching to outer,edge, and from each corner of the notch on either side of the tubercles

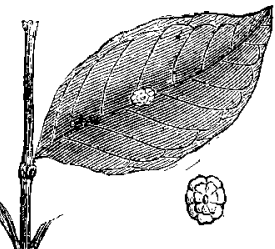
issues a long filament nearly as long as the insect, Fig. 25. with. a short hair on each side.

These crawl round for two or three days after hatching, searching for a suitable place to insert their beak. After inserting their beak they become stationary, and there soon after begins to form over them a waxy secretion in the form of small white globules, which is quite plainly visible in a few days in the form of small, white, round, elevated spots surround- 
ing the insect, particularly just above the spiracles. As it increases in size, the limbs, which are of no more use, gradually disappear, and on reaching maturity it forms a brownish pupa, which on cutting open is found filled with eggs. These are elliptical, .o I of an inch in length, and of a pale yellow color. In one of the cases I counted one hundred and five eggs.

NUMBER OF EROODS.

During the year there are three broods ; the first brood hatches from last of April to middle of May; the second, from middle of July to first week in August ; the third, from last week of August to middle of September. One can form some idea of their prolificness, by supposing nothing prevents the first hundred eggs from hatching; this would give one hundred insects, which in turn produce their one hundred eggs, making in all 10,000 by second brood; these each producing a hundred would give a grand total of $1,000,000$. One million-think of it--the produce of one scale insect in a year !

Thanks, however, to that immutable law which governs the universe, it has its enemies to prey upon and keep it from increasing too fast.

NATURAL ENEMIES.

The twice-stabbed Lady-bug Chilocorus bivulnerus, the blood-red Ladybug Cycloneda sanguinea, and an ichneumon fy, are its principal foes. I. have also detected a small white mite, about $\frac{1}{3}{ }^{3}$ of an inch long, among the eggs and old scales; but whether it be an enemy or not I cannot say, as I have failed to detect it doing any damage. I'm inclined to think. it merely feeds upon the decaying matter of the old scale.

I have not not yet met with the male of this species, but hope to do so before long.

The cut will give an admirable idea of the scale.

\section{NORTH AMERICAN MOTHS.}

BY A. R. GROTE.

(Continued from Page 244.)

Oncocnemis levis, n. s.

Primaries much shaded with black over dusty ochrey. Markings fine, neat, distinct. The lines black, with narrow included dusty ochrey shades. Half-line present, Anterior line with three dentations. Claviform long, 